\title{
ANTAGONISTIC ACTIVITY OF A NEW STRAIN OF TRICHODERMA VIRIDE AND ITS EFFECT ON MICROMYCETES POPULATIONS IN THE ROOT ZONE OF CORN PLANTS
}

\author{
E. P. Kopilov, A. A. Pavlenko, G. V. Tsekhmister, A. S. Kyslynska \\ Institute of Agricultural Microbiology and Agroindustrial Manufacture, NAAS \\ 97 Shevchenka str., Chernihiv, 14035, Ukraine; e-mail: tolik.pavlenko@gmail.com
}

Goal. To investigate the antagonistic activity of a new strain of Trichoderma viride F-100076 and its effect on the formation of micromycetes populations in the root zone of corn plants under field conditions. Methods. The antagonistic activity of T. viride F-100076 was studied by the method of mixed (counter) cultures on wort agar using phytopathogenic fungi, which were isolated and identified in the Laboratory of Plant-Microbial Interactions. The appearance and type of relationship were registered using a scale modified by Symonian and Mamikonian. The number of micromycetes was determined by the method of soil dilutions. Isolation, accounting and cultivation of fungi was carried out according to conventional methods. Micromycetes were identified according to the determinants appropriate for a specific systematic group of micromycetes. Results. It was found that T. viride IMB F-100076 is characterized by high antagonistic activity against a wide range of phytopathogenic fungi, showing hyperparasitism as early as on the eighth day. The highest antagonistic activity of the strain was found against: Alternaria radicina, Acremonium strictum, Acremonium cucurbitacearum, Fusarium oxysporum var. orthoceras, Fusarium moniliforme var. lactis, Torula expansa (5 points on the corresponding Symonian and Mamikonian scale). Data from the mycological analysis of the sod-podzolic soil of the corn rhizosphere showed that the mycocenosis of the sod-podzolic soil of the corn rhizosphere was formed by micromycetes belonging to the genera Acremonium Link, Cladosporium Corda, Fusarium Link:Fr, Gliocladium Corda, Mucor Mich, Penicillium Link:Fr, Rhizopus Ehrenb, Trichoderma Hers, among which the most represented were micromycetes of the genus Penicillium (59\%). The total number of fungi in the control variant was $291.00 \pm 79.67$ thousand CFU/g of soil. The introduction of straw affected both the total number of micromycetes and the genus composition of fungi. The total number of fungi in the variant with straw increased 2.6 times and amounted to $744.00 \pm 114.67$ thousand CFU/g of soil. The number of representatives of all studied genera of micromycetes also increased. In addition, the introduction of straw provoked the development of fungi of Bipolaris and Fusarium genera, which can be considered a negative outcome since representatives of these species are commonly recognised as pathogens of root diseases. Application of the fungus antagonist T. viride IMB F-100076 to the soil along with straw did not significantly affect the total number of micromycetes. At the same time, a displacement of fungi of the genus Bipolaris and Fusarium from the rhizosphere of corn was registered. The number of fusaria decreased from $96.00 \pm 5.44$ to $23.00 \pm 2.32$ thousand CFU/g of soil or almost 4 times and reached the level of the control variant. Fungi of the genus Bipolaris in the variant with the introduction of trichoderma were not detected. Conclusion. The antagonist fungus T. viride F-100076, introduced into the soil along with straw, strikes root in the soil and exhibits antagonistic activity against micromycetes of the genera Bipolaris and Fusarium, which are commonly represented by root rot pathogens of many crops. Thus, the new strain T. viride F-100076 allows increasing the antagonistic potential of the rhizosphere soil of corn and protecting plants from pathogens.

Key words: micromycetes, antagonist fungus, Trichoderma, corn, wheat straw, phytopathogenic fungi. 
Introduction. Among the bioagents of microbial preparations for plant protection from pathogens of root diseases, the representatives of widespread soil micromycetes of the genus Trichoderma Pers are of the greatest interest. The action of fungi of the genus Trichoderma on microorganisms is due to their ability to form antibiotics (gliotoxin, viridine, alamecin and others), hydrolytic enzymes, as well as the ability to actively compete with other microorganisms in the consuming of nutrient substrate and to show hyperparasitic activity against large spectrum of micromycetes. The search for strains of fungi of the genus Trichoderma - potential agents of biopreparations, is carried out in many scientific institutions around the world. Trichodermin and its modifications was created on the basis of active strains of Trichoderma genus. Fungi of the genus Trichoderma with high cellulase activity are also known. It is expedient and timely to search for natural highly active strains of fungi of the genus Trichoder$m a$, which are characterized by high antagonistic activity against plant disease pathogens and the ability to destroy agricultural waste. Creation of double-acting biopreparations on the basis of such strains will accelerate the destruction of plant residues while protecting crops from pathogens.

Analysis of recent studies and publications. It is known that among the modern measures of crop protection the chemical method of plant protection continues to dominate. However, for many developed countries, the need to reduce pesticide use has become urgent. This is caused by a number of negative phenomena that occur with the widespread use of chemical methods, namely: accumulation of so-called pesticide residues that can migrate in different systems, resulting in contamination of agricultural products and their entry into the human body. In many cases, pesticides have a biocidal action on a beneficial biota. Furthermore, the adaptation of harmful species is registered everywhere, i. e. pesticide-resistant forms appear in populations of pests and phytopathogens. The incidence of resistant forms of pests outrides the creation of new preparations. All this encourages the limitation of chemicals and the search for effective and environmentally friendly plant protection systems alternative to the chemical method. Biological method, in particular, the use of microbial preparations, is an alternative to the chemical method.

Trichoderma fungi are promising bioagents of microbial preparations to protect crops from pathogens. They are increasingly attracting the attention of researchers and more than $90 \%$ of biofungicides are based on them [1]. T. harzianum, $T$. viride, $T$. virens are the most common strains used to control fungal diseases. Representatives of the genus Trichoderma are antagonists of such phytopathogens as Phitophthora infestans, Alternarsa alternata and Botrytis cinerea [2-3], Verticillium tricorpus, V. dahliae, $V$. albo-atrum [4]. Trichoderma reduces the infectious background of soils, restoring their suppressiveness, i. e. the ability to inhibit pathogenic microbiota in natural biocenoses [5].

High antagonistic activity of fungi of the genus Trichoderma is due to various mechanisms of action: competition, hyperparasitism and antibiosis. One of the determining factors in the dominance of one or another species in the agrocenosis is the ability to grow rapidly, due to severe competition for nutrient substrate through the synthesis of siderophores - low molecular weight compounds of various chemical nature. Siderophores are synthesized by soil microorganisms and efficiently bind iron ions, which are then supplied to plants that are in symbiotic relationships with the corresponding microorganisms. A role of siderophores in antagonistic relationships with soil phytopathogens is important, since they successfully compete for iron ions, being in the tissues of the host plant. This ability has been shown for some species of Trichoderma, but most siderophores have not been characterized [5]. There is a characteristic for only three siderophores of the fungus $T$. virens: monohydroxymate (cis- and transfusarinin), trans-fusarinin dipeptide and trimer disdepsipeptide-copragen [5].

Hyperparasitism is based on a direct contact between the antagonist and the pathogen. Lytic enzymes play a leading role in this process. Trichoderma fungi are capable of synthesizing extracellular hydrolases, in particular, endochitinases, proteases, glucanases, lipases, xylanases, mannases, pectinases, pectinliases, amylase, phospholipases, RNAases, DNAases and others. Chitinolytic and glucanolytic enzymes catalyse the hydrolysis of cell walls of phytopathogens, as they destroy polymers that do not occur in 
plant cells [5], and proteases reduce the enzymatic activity of pathogens [1].

The antibiosis involves indirect effect and is based on the synthesis of substances that have an inhibitory or fatal effect on phytopathogens. More than 100 secondary metabolites are known to be characterized by antibiotic activity, and they are produced by Trichoderma fungi. Among them are gliotoxin, viridine, trichodermin, sacucacillin, alamethicin, dermadin, etc. [6]. Trichoderma produces both volatile (ethylene, alcohols, aldehydes, ketones) and nonvolatile metabolites, including protein antibiotics (peptobiols) [5]. The combined action of lytic enzymes with antibiotics provides a higher level of antagonism compared to their action alone. The synergistic action of hydrolases and antibiotics is known, and the degradation of phytopathogenic cell walls is accompanied by inhibition of the growth rate of the fungus [5].

Trichoderma fungi are not only active antagonists of phytopathogens, they are also able to produce substances of phytohormonal nature, which improve plant growth and development, in particular, increase the content of chlorophylls, proteins, carbohydrates, germination energy, similarity, aboveground and root system mass [7]. The recent studies have shown that fungi of the genus Trichoderma are able to form symbiotic associations with plants similar to mycorrhizal fungi. Under the influence of such symbiotic associations, the availability of nutrients in plants $(\mathrm{N}, \mathrm{P})$ increases, which contributes to their better growth and development. Furthermore, such plants are more resistant to phytopathogens. For example, the positive effect of $T$. harzianum on the root system and aboveground mass of cucumber plants was noted [1]. It is emphasised that the synthesis of substances with restrictive properties helps the trichoderma to colonize the roots of plants and promotes the formation of associations, causing the functional interactions between micro- and macro-organism [8].

Data are available that $T$. harzianum is able to penetrate the epidermis of the root of cucumber plants, thereby inducing the synthesis of peroxidases and phenolic compounds, which in turn strengthened the cell wall of plants and partially limited the penetration of pathogens by inducing systemic immunity [9]. Trichoderma synthesizes 6-pentyl-alpha-pyrone (6PP) and peptobiols, which act as elicitors and acti- vate protective mechanisms in the host plant [10-11].

The increase in crop yield under the influence of fungi of the genus Trichoderma is due to the synergistic effect of the mechanisms described above.

Therefore, the search for new effective strains of antagonist fungi of the genus Trichoderma and the development of biopreparations on their basis is an essential condition for the successful application of new plant protection products that can protect yields and improve the environment.

Materials and methods. Determination of antagonistic activity was performed using phytopathogenic fungi, which were isolated and identified in the Laboratory of Plant-Microbial Interactions at the Institute of Agricultural Microbiology and Agroindustrial Manufacture of the NAAS, namely: Alternaria radicina, which causes early blight of potatoes, tomatoes, carrots; Acremoniumstrictum - phytopathogen of most monocotyledonous and dicotyledonous crops, which causes wilting of plant leaves; Acremonium cucurbitacearum, which is the causative agent of pumpkin family acremoniasis; Aureobasidium pullulans is a phytopathogen that causes diseases of shoots of agricultural plants; Fusarium oxysporum is the causative agent of root rot and fusarium wilt, Fusarium oxysporum var. orthoceras is a phytopathogen that causes vascular (tracheomycosis) wilting of crops: wheat, rapeseed, tomatoes; Fusarium moniliforme var. lactis which is the causative agent of fusarium rot of corn stalks; Fusarium solani is the causative agent of root diseases of nightshade family and cereals; Rhizoctonia violaceae which causes red root rot or rhizocteniasis; Stachybotrys alternans affects roughage (mainly straw); Thielaviopsis basicola affects the roots and root system of legumes; Torula expansa affects roughage.

The antagonistic activity of $T$. viride F-100076 was studied by the method of mixed (counter) cultures [12-13] on wort agar (4-5\% dry matter) in $90 \mathrm{~mm}$ Petri dishes with a layer of medium $6 \mathrm{~mm}$ thick. Petri dishes were placed in a thermostat at $26 \pm 2{ }^{\circ} \mathrm{C}$. The experiment was repeated three times. Accounting was performed on the day 3 and 8 of cultivation.

The study of the mycocenosis of the root zone of corn plants was carried out under the conditions of a field experiment with corn, 
which was performed according to the scheme: 1 - control; 2 - Introduction of straw; 3 introduction of straw treated with $T$. viride F-100076 $\left(2 \times 10^{5} \mathrm{CFU}\right.$ per $1 \mathrm{~g}$ of straw $)$. In the experiment, corn hybrid Kremin 200 SV was cultivated. Straw and nitrogen fertilizers were applied during autumn plowing at the rate of $15 \mathrm{~kg}$ of active substance per 1 tonne of straw. Mineral fertilizers in the dose of $\mathrm{N}_{60} \mathrm{P}_{30} \mathrm{~K}_{90}$ were introduced during spring plowing. The accountable area of the plot is $8.5 \mathrm{~m}^{2}$. The experiment was repeated 5 times.

The number of micromycetes was determined by the method of Waksman soil dilutions. Isolation, accounting and cultivation of fungi was carried out according to generally accepted methods [14]. Cultural and morphological characteristics of the fungi were studied on wort agar with the addition of streptomycin in the amount of $240 \mathrm{IU}$ per $1 \mathrm{~mL}$ of medium to inhibit bacterial growth. On the day 3-4, the number of colony-forming units (CFU) was counted, and on the day 7-8, micromycetes were isolated in pure culture for further determination according to the described methods [14].

Morphological features of micromycetes were studied using a light microscope Delta Optical Evolution 300 in accordance with the relevant determinants [15-21].

Results and discussion. The study of antagonistic activity of $T$. viride F-100076 was performed by the method of counter cultures. The obtained results showed that $T$. viride IMB F-100076 is characterized by high antagonistic activity against a wide range of phytopathogenic fungi, showing hyperparasitism as early as on the eighth day (Table 1). The highest antagonistic activity of the strain was found in relation to: Al. radicina, Ac. strictum, Ac. cucurbitacearum, $F$. oxysporum, $F$. solani, $F$. oxysporum var. orthoceras, $F$. moniliforme var. lactis, $T$. expansa ( 5 points respectively by Symonian and Mamikonian scale) (Fig. 1-3). At the same time, $T$. viride F-100076 inhibited growth and completely colonized pathogenic colonies showing hyperparasitism.

Table 1. Antagonistic activity of Trichoderma viride IMB F-100076 against phytopathogenic fungi (laboratory experiment, day 8)

\begin{tabular}{|l|c|c|}
\hline \multicolumn{1}{|c|}{ Strains } & $\begin{array}{c}\text { Reaction } \\
\text { type }\end{array}$ & Points \\
\hline Alternaria radicina & E & 5 \\
\hline Acremonium strictum & E & 5 \\
\hline $\begin{array}{l}\text { Acremonium } \\
\text { cucurbitacearum }\end{array}$ & $\mathrm{E}$ & 5 \\
\hline Fusarium oxysporum & $\mathrm{E}$ & 5 \\
\hline Fusarium solani & $\mathrm{E}$ & 5 \\
\hline $\begin{array}{l}\text { Fusarium oxysporum } \\
\text { var. orthoceras }\end{array}$ & $\mathrm{E}$ & 5 \\
\hline $\begin{array}{l}\text { Fusarium moniliforme } \\
\text { var. lactis }\end{array}$ & $\mathrm{E}$ & 5 \\
\hline Torula expansa & $\mathrm{E}$ & 5 \\
\hline Rhizoctonia violaceae & $\mathrm{D}$ & 4 \\
\hline Aureobasidium pullulans & $\mathrm{D}$ & 4 \\
\hline Stachybotrys alternans & $\mathrm{D}$ & 4 \\
\hline
\end{tabular}

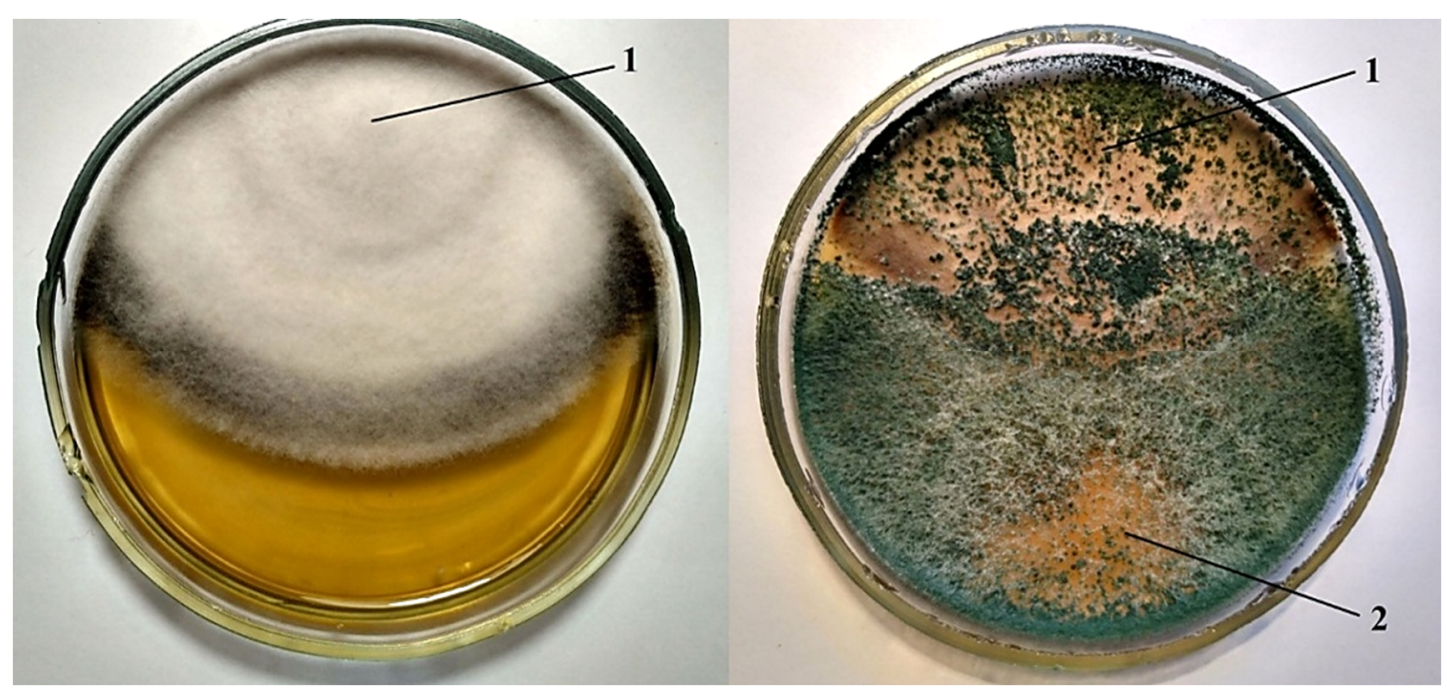

Fig. 1. Antagonistic interaction between T. viride IMB F-100076 and phytopathogenic micromycete Aureobasidium pullulans (8 days): 1 - A. pullulans; 2 - T. viride IMB F-100076. 


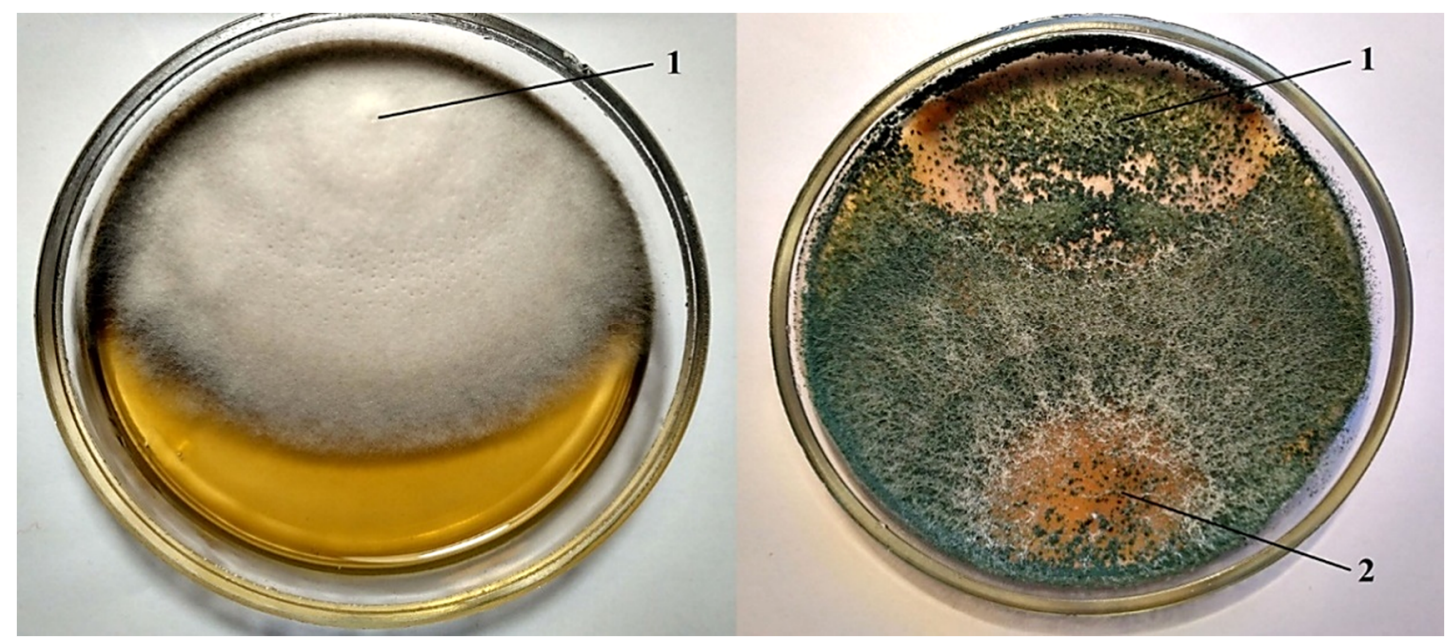

Fig. 2. Antagonistic interaction between T. viride IMB F-100076 and phytopathogenic micromycete Stachybotrys alternans (8 days): $1-S$. alternans; 2 - T. viride IMB F-100076.
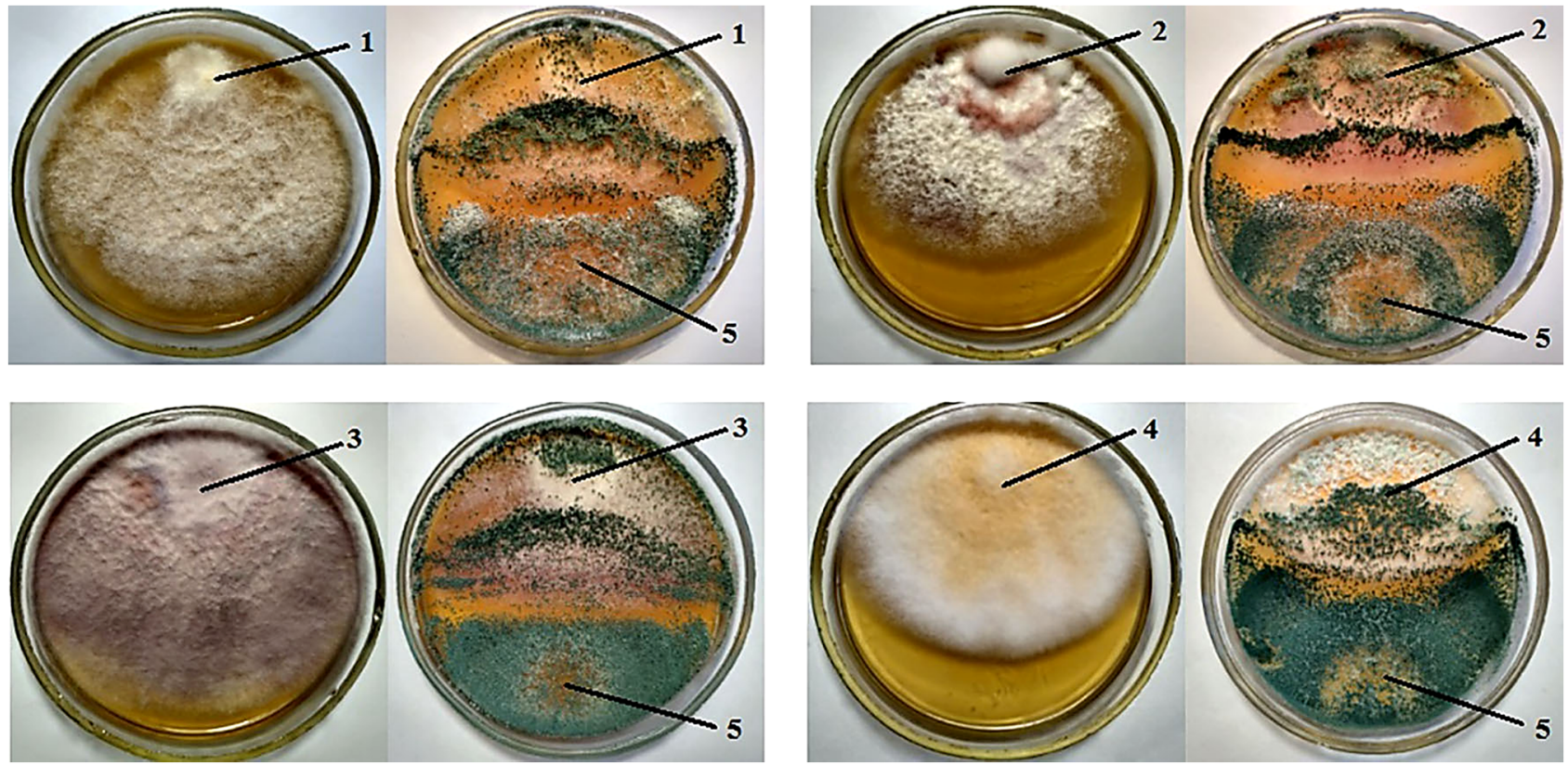

Fig. 3. Antagonistic interaction between T. viride IMB F-100076 and phytopathogenic micromycetes (8 days): 1 - Fusarium solani; 2 - Fusarium oxysporum; 3 - Fusarium moliniforme var. lactis; 4 - Fusarium oxysporum var. orthoceras; 5 - T. viride IMB F-100076.

T. viride IMB F-100076 had a relatively high activity (4 points) against Rhizoctonia violaceae, Aureobasidium pullulans, Stachybotrys alternans (Table 1).

Thus, the new strain $T$. viride IMB F-100076, showing high activity against phytopathogenic fungi, can be used for pre-sowing treatment of crops in order to protect them from pathogens of root diseases.

It is known that the nature of the interaction between introduced and aboriginal microorganisms can change when introduced into the soil. Underestimation of the ability of the microorganism to take root in the soil and counteract the pathogenic microbiota can lead to a lack of positive effect. The use of antagonist fungi to protect plants from pathogens can be effective only taking into account the influence of environmental factors, species composition of saprotrophic and pathogenic microorganisms, soil and climatic characteristics, as well as the relationship between aboriginal and introduced microorganisms. To determine the effect of the fungus antagonist $T$. viride IMB F-100076 on micromycetes directly in the soil, a field experiment was conducted, which provided variants with and without the introduction of winter wheat straw at a rate of $70 \mathrm{~kg} / \mathrm{ha}$.

The obtained data of mycological analysis of sod-podzolic soil of corn rhizosphere are 
provided in Table 2. The obtained data suggest that the mycocenosis of the sod-podzolic soil of the corn rhizosphere was formed by micromycetes belonging to the genera Acremonium Link, Cladosporium Corda, Fusarium Link:Fr, Gliocladium Corda, Mucor Mich, Penicillium Link:Fr, Rhizopus Ehrenb, Trichoderma Hers, among which micromycetes of the genus Penicillium were the most represented (59\%). The total number of fungi in the control variant was $291 \pm$ \pm 79.67 thousand CFU (Table 2).

The introduction of straw affected both the total number of micromycetes and the genus composition of fungi. The total number of fungi in the variant with straw increased 2.6 times and amounted to $744 \pm 114.67$ thousand $\mathrm{CFU} / \mathrm{g}$ of soil. The number of representatives of all studied genera of micromycetes also increased. In addition, the introduction of straw provoked the development of micromycetes of the genus $\mathrm{Bi}$ polaris, which can be considered a negative outcome since it is known that causative agents of helminthosporium blight is common among representatives of this species. Helminthosporium blight of corn leaves is a characteristic disease for the zone of Ukrainian Polissia, the harmfulness of which is 6 to $27 \%$. The number of micromycetes of the genus Bipolaris in the variant with straw was at the level of $21 \pm 3.10$ thousand CFU/g of soil. The introduction of straw also led to a significant increase in the number of micromycetes of the genus Fusari$u m$ : from $25 \pm 3.12$ to $96 \pm 5.44$ thousand $\mathrm{CFU} / \mathrm{g}$ of soil or almost 4 fold (Table 2). This can also be considered as an undesirable trend, as fusaria can cause root rot and adversely affect crop yields, in particular corn.

The introduction of the antagonist fungus T. viride IMB F-100076 into the soil along with straw had almost no effect on the total number of micromycetes, but there was a displacement of fungi of the genus Bipolaris and Fusarium from the corn plant rhizosphere. The number of fusaria decreased from $96 \pm 5.44$ to $23 \pm 2.32$ thousand $\mathrm{CFU} / \mathrm{g}$ of soil or almost 4-fold and reached the level of the control variant. Bipolaris fungi in the variant with the introduction of trichoderma were not detected at all (Table 2).

Conclusion. The antagonist fungus $T$. viride F-100076, introduced into the soil along with the straw, takes root in the soil and exhibits antagonistic activity against micromycetes of the genera Bipolaris and Fusarium, among which root rot pathogens of many crops are common. Thus, the new strain $T$. viride F-100076 allows to increase the antagonistic potential of the rhizosphere soil of corn and to protect plants from pathogens.

\section{REFERENCES}

1. Błaszczyk, L., Siwulski, M., Sobieralski, K., Lisiecka, J., \& Jędryczka, M. (2014). Trichoderma sp. - application and prospects for use in organic farming and industry. J. Plant Prot. Res., 54(4), 309-317. https://doi.org/10.2478/jppr-2014-0047

2. Nevmerzhitskaya, O. M., \& Nurmuhammedov, A. K. (2012). Effektivnost biopreparatov protiv vozbuditeley buroy gnili korneplodov [The effectiveness of biological products against pathogens of brown rotof root crops]. Saharnaya svekla - Sugar beet, 6, 38-40 [in Russian].

3. Stadnichenko, M. A. (2011). Perspektivy biologicheskogo kontrolya vozbuditelya botritioza na paslonovykh kulturakh [Prospects for the biological control of the causative agent of botrythiosis in paslon cultures]. Vestnik $B G U-B S U$ Bulletin, 2, 49-55 [in Russian].

4. Fotoohiyan, Z., Rezaee, S., Bonjar, G., Mohammadi, A. H, \& Moradi, M. (2017). Biocontrol potential of Trichoderma harzianum in controlling wilt disease of pistachio caused by Verticillium dahlia. J. Plant Prot. Res., 57, 185-193. https://doi.org/ 10.1515/jppr-2017-0025

5. Alimova, F. K. (2005). Sovremennaya sistema Trichoderma / Hypocrea [Modern Trichoderma / Hypocrea system]. Uchenyie zapiski Kazanskogo universiteta - Scientific notes of Kazan University, 147(2), 28-56 [in Russian].

6. Bohdanov, A. I., \& Titova, J. A. (2014). Antagonisticheskaya aktivnost shtammov Trichoderma asperellum - produtsentov multikonversionnykh biopreparatov [Antagonostic activity of the strains Trichoderma asperellum - producers of multiconversion biological products]. Vestnik zashhity rastenij - Plant Protection Bulletin, 1, 48-52 [in Russian].

7. Golovanova, T. I., Dolinskaya, E. V., \& Kostitsyna, Y. N. (2008). Vliyanie gribov roda Trichoderma na rostovye protsesy pshenitsy [The influence of fungi of the genus Trichoderma on the growth processes of wheat]. Isledovano $v$ Rossii - Investigated in Russia, 13, 173-182 [in Russian].

8. Howell, C. R. (2003). Mechanisms employed by Trichoderma species in the biological control of plant diseases: the history and evolution of current concepts. Plant Dis., 87, 4-10. https://doi.org/ 10.1094/PDIS.2003.87.1.4

9. Yedidia, I., Benhamou, N., \& Chet, I. (1999). Induction of defense responses in cucumber plants (Cucumis sativus L.) by the biological agent Tricho- 


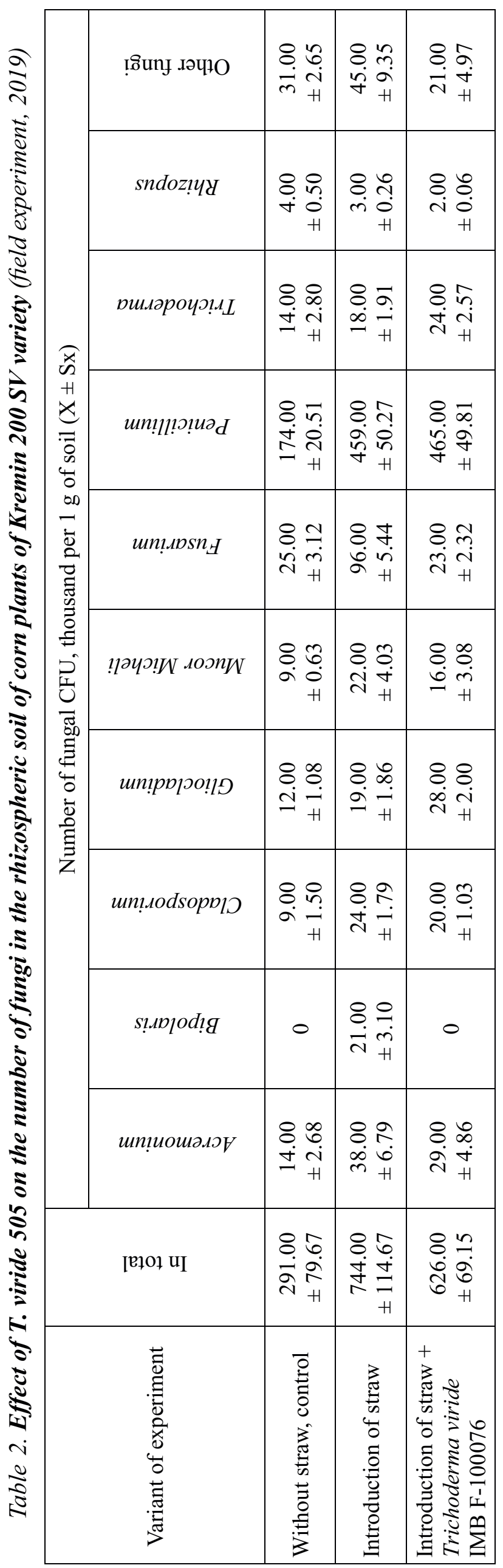


derma harzianum. Appl. Environ. Microbiol., 65(3), 1061-1070. https://doi.org/10.1128/AEM.65.3.10611070.1999

10. Vinale, F., Sivasithamparam, K., Ghisalberti, E.L., Marra, R., Woo, S. L., \& Lorito, M. (2008). Trichoderma-plant-pathogen interactions. Soil Biol Biochem., 40, 1-10. https://doi.org/10.1016/j.soilbio. 2007.07.002

11. Viterbo, A., Wiest, A., Brotman, Y., Chet, I., \& Kenerley, C. (2007). The 18mer peptaibols from Trichoderma virens elicit plant defence responses. Mol Plant Pathol., 8, 737-746. https://doi.org/ 10.1111/j.1364-3703.2007.00430.x

12. Volkogon, V. V. (Ed.). (2010). Eksperimentalna gruntova mikrobiologiya: monografiia [Experimental soil microbiology: Monograph]. Kyiv: Agrarna nauka [in Ukrainian].

13. Simonyan, S. A., \& Mamikonyan, T. S. (1982). Vzaimodeytvie komponentov karpofilnykh mikosinuziy $\mathrm{v}$ eksperimente [The interaction of the components of carpophilic mycosinusia in the experiment]. Mikologiya i fitopatologiya - Mycology and phytopathology, 16(3), 219-255 [in Russian].

14. Bilay, V. I. (Ed.). (1982). Metody eksperi- mentalnoy mikologii [Methods of experimental mycology]. Kiev: Naukova Dumka [in Russian].

15. Kirilenko, T. S. (1977). Atlas rodov pochvennykh gribov [Atlas of genera of soil fungi]. Kiev: Naukova Dumka [in Russian].

16. Bilay, V. I. (Ed.). (1984). Mikromitsety pochv [Soil micromycetes]. Kiev: Naukova Dumka [in Russian].

17. Litvinov, M. A. (1967). Opredelitel mikroskopicheskikh pochvennykh gribov [Key to microscopic soil fungi]. Leningrad: Science [in Russian].

18. Bilay, V. I. (1977). Fuzarii [Fusaria]. Kiev: Naukova Dumka [in Russian].

19. Pidoplichko, N. M. (1977). Griby-parazity kulturnykh rasteniy (T. 2) [Fungi parasites of cultivated plants (Vol. 2)]. Kiev: Naukova Dumka [in Russian].

20. Pidoplichko, N. M. (1977). Griby-parazity kulturnykh rasteniy (T. 1) [Fungi parasites of cultivated plants (Vol. 1)]. Kiev: Naukova Dumka [in Russian].

21. Pidoplichko, N. M. (1978). Griby-parazity kulturnykh rasteniy (T. 3) [Fungi parasites of cultivated plants (Vol. 3)]. Kiev: Naukova Dumka [in Russian].

Received 03.06.2020

https://doi.org/10.35868/1997-3004.31.16-25

УДК 632.937.1.04:632.937.1.02:632.937.1.05:632.937.14

\title{
АНТАГОНІСТИЧНА АКТИВНІСТЬ НОВОГО ШТАМУ TRICHODERMA VIRIDE ТА ЙОГО ВПЛИВ НА УГРУПОВАННЯ МІКРОМЦЕТІВ КОРЕНЕВОЇ ЗОНИ РОСЛИН КУКУРУДЗИ
}

\author{
Є. П. Копилов, А. А. Павленко, Г. В. Цехмістер, А. С. Кислинська
}

Інститут сільськогосподарської мікробіології та агропромислового виробництва НААН, м. Чернігів e-mail: tolik.pavlenko@gmail.com

Мета. Дослідити антагоністичну активність нового штаму T. viride F-100076 та його вплив на формування угруповання мікромічетів кореневої зони рослин кукурудзи за умов польового досліду. Методи. Антагоністичну активність Trichoderma viride F-100076 досліджували методом змішаних (зустрічних) культур на сусло-агарі з використанням фітопатогенних грибів, які було виділено та ідентифіковано в лабораторії рослинно-мікробних взаємодій. Відзначали зовнішній вигляд і тип відносин, використовуючи шкалу в модифікачіі Симоняна і Маміконяна. Визначення чисельності мікроміцетів здійснювали за методом трунтових розведень. Виділення, облік $і$ культивування грибів здійснювали за загальноприйнятими методиками. Ідентифікацію мікроміцетів проводили за відповідними для конкретної систематичної групи мікроміцетів визначниками. Результати. Встановлено, щзо T. viride IMB F-100076 характеризується високою антагоністичною активністю щодо широкого спектру фітопатогенних грибів, виявляючи гіперпаразитизм вже на восьму добу. Найвищу антагоністичну активність штам виявив щзодо: Alternaria radicina, Acremonium strictum, Acremonium cucurbitacearum, Fusarium oxysporum var. orthoceras, Fusarium moniliforme var. 
lactis, Torula expansa (5 балів за відповідною шкалою Симоняна та Маміконяна). Дані мікологічного аналізу дерново-підзолистого трунту ризосфери кукурудзи засвідчили, що мікоценоз дерново-підзолистого трунту ризосфери кукурудзи формували мікроміцети, які належали до родів Acremonium Link, Cladosporium Corda, Fusarium Link:Fr, Gliocladium Corda, Mucor Mich, Penicillium Link:Fr, Rhizopus Ehrenb, Trichoderma Hers, серед яких найбільш представленими були мікроміџети роду Репісіllium (59\%). Загальна кількість грибів у контрольному варіанті складала 291,00 \pm 79,67 тис. КУО/2 грунту. Внесення соломи позначилося як на загальній кількості мікромічетів, так і на родовому складі грибів. Загальна кількість грибів у варіанті з соломою збільшилася в 2,6 раза і склала 744,00 $\pm 114,67$ тис. КУО/г грунту. Збільшилася також $і$ чисельність представників всіх досліджених родів мікромічетів. Крім того, внесення соломи спровокувало розвиток грибів родів Bipolaris та Fusarium, що можна вважати негативним наслідком, адже відомо, що серед представників зазначених видів часто трапляються збудники кореневих хвороб. Внесення в трунт одночасно із соломою грибаантагоніста T. viride IMB F-100076 не впливало істотно на загальну кількість мікроміцетів. Водночас мало місие витіснення з ризосфери кукурудзи грибів роду Bipolaris $i$ Fusarium, а чи-

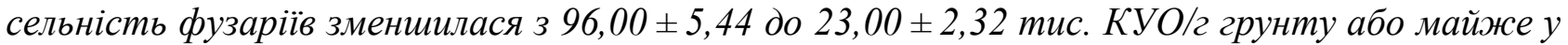
4 рази і досягла рівня контрольного варіанту. Гриби роду Bipolaris у варіанті з внесенням триходерми не виявлялися. Висновки. Гриб-антагоніст T. viride F-100076, внесений у трунт одночасно із соломою, приживається в трунті та виявляє антагоністичну активність щодо мікромічетів родів Bipolaris i Fusarium, серед яких часто трапляються збудники кореневих гнилей багатьох сільськогосподарських культур. Отже, новий штам T. viride F-100076 дозволяє підвищити антагоністичний потенціал ризосферного трунту кукурудзи та захистити рослини від збудників захворювань.

Ключові слова: мікромічети, гриб-антагоніст, Trichoderma, кукурудза, пшенична солома, фітопатогенні гриби.

\section{ЦИТОВАНА ЛІТЕРАТУРА}

1. Błaszczyk L., Siwulski M., Sobieralski K., Lisiecka J., Jędryczka M. Trichoderma sp. — application and prospects for use in organic farming and industry. J. Plant Prot. Res. 2014. № 54 (4). P. 309 317. https://doi.org/10.2478/jppr-2014-0047

2. Невмержицкая О. М., Нурмухаммедов А. К. Эффективность биопрепаратов против возбудителей бурой гнили корнеплодов. Сахарная свекла. 2012. № 6. С. 38-40.

3. Стадниченко М. А. Перспективы биологического контроля возбудителя ботритиоза на пасльоновых культурах. Вестник БГУ. Сер. 2011. № 2. C. 49-55.

4. Fotoohiyan Z., Rezaee S., Bonjar G., Mohammadi A. H, Moradi M. Biocontrol potential of Trichoderma harzianum in controlling wilt disease of pistachio caused by Verticillium dahlia. J. Plant Prot. Res. 2017. № 57. P. 185-193. https://doi.org/ 10.1515/jppr-2017-0025

5. Алимова Ф. К. Современная система Trichoderma / Нуросrea. Ученые записки Казанского университета. Сер. биол. Естественные науки. 2005. № 147 (2), С. 28-56.

6. Богданов А. И., Титова Ю. А. Антагонистическая активность штаммов Trichoderma asperellum - продуцентов мультиконверсионных биопрепаратов. Вестник защиты растений. 2014. № 1. C. 48-52.

7. Голованова Т. И., Долинская Е. В., Кости- цына Ю. Н. Влияние грибов рода Trichoderma на ростовые процесы пшеницы. Иследовано в России. 2008. № 13. С. 173-182.

8. Howell C. R. Mechanisms employed by Trichoderma species in the biological control of plant diseases: the history and evolution of current concepts. Plant Dis. 2003. № 87. P. 4-10. https://doi.org/10.1094/PDIS.2003.87.1.4

9. Yedidia I., Benhamou, N., Chet I. Induction of defense responses in cucumber plants (Cucumis sativus L.) by the biological agent Trichoderma harzianum. Appl. Environ. Microbiol. 1999. № 65(3). P. 1061-1070. https://doi.org/10.1128/AEM.65.3. 1061-1070.1999

10. Vinale F., Sivasithamparam K., Ghisalberti E. L., Marra R., Woo S.L., Lorito M. Trichodermaplant-pathogen interactions. Soil Biol Biochem. 2008. № 40. P. 1-10. https://doi.org/10.1016/ j.soilbio.2007.07.002

11. Viterbo A., Wiest A., Brotman Y., Chet I., Kenerley C. The 18 mer peptaibols from Trichoderma virens elicit plant defence responses. Mol Plant Pathol. 2007. № 8. P. 737-746. https://doi.org/ 10.1111/j.1364-3703.2007.00430.x

12. Експериментальна грунтова мікробіологія : монографія / Волкогон В. В., Надкернична О. В., Токмакова Л. М. та ін.; за наук. ред. В. В. Волкогона. К. : Аграрна наука, 2010. 464 с.

13. Симонян С. А., Мамиконян Т. С. Взаимодейтвие компонентов карпофильных микоси- 
нузий в эксперименте. Микология и фитопатология. 1982. № 16(3). С. 219-255.

14. Методы экспериментальной микологии : справочник / Под ред. В. И. Билай. К. : Наук. думка, $1982.549 \mathrm{c}$.

15. Кириленко Т. С. Атлас родов почвенных грибов. К. : Наук. думка, 1977. 128 с.

16. Микромицеты почв / Под ред. В. И. Билай. К. : Наук. думка, 1984. 264 с.

17. Литвинов М. А. Определитель микроскопических почвенных грибов. Ленинград : Наука, 1967. 303 с.
18. Билай В. И. Фузарии. К. : Наук. думка, 1977. $444 \mathrm{c}$.

19. Пидопличко H. М. Грибы-паразиты культурных растений (Т. 2). К. : Наук. думка, $1977.300 \mathrm{c}$.

20. Пидопличко Н. М. Грибы-паразиты культурных растений (Т. 1). К. : Наук. думка, 1977. $296 \mathrm{c}$.

21. Пидопличко H. M. Грибы-паразиты культурных растений (Т. 3). К. : Наук. думка, 1978. $232 \mathrm{c}$.

Отримано 03.06.2020 